Louisiana State University

LSU Digital Commons

7-1-2016

\title{
A New Genus and Species of Blind Sleeper (Teleostei: Eleotridae) from Oaxaca, Mexico: First Obligate Cave Gobiiform in the Western Hemisphere
}

\author{
Stephen J. Walsh \\ United States Geological Survey \\ Prosanta Chakrabarty \\ Louisiana State University
}

Follow this and additional works at: https://digitalcommons.Isu.edu/biosci_pubs

\section{Recommended Citation}

Walsh, S., \& Chakrabarty, P. (2016). A New Genus and Species of Blind Sleeper (Teleostei: Eleotridae) from Oaxaca, Mexico: First Obligate Cave Gobiiform in the Western Hemisphere. Copeia, 104 (2), 506-517. https://doi.org/10.1643/Cl-15-275 


\title{
A New Genus and Species of Blind Sleeper (Teleostei: Eleotridae) from Oaxaca, Mexico: First Obligate Cave Gobiiform in the Western Hemisphere
}

\author{
Authors: Walsh, Stephen J., and Chakrabarty, Prosanta \\ Source: Copeia, 104(2) : 506-517 \\ Published By: The American Society of Ichthyologists and \\ Herpetologists
}

URL: https://doi.org/10.1643/Cl-15-275

BioOne Complete (complete.BioOne.org) is a full-text database of 200 subscribed and open-access titles in the biological, ecological, and environmental sciences published by nonprofit societies, associations, museums, institutions, and presses.

Your use of this PDF, the BioOne Complete website, and all posted and associated content indicates your acceptance of BioOne's Terms of Use, available at www.bioone.org/terms-of-use.

Usage of BioOne Complete content is strictly limited to personal, educational, and non - commercial use. Commercial inquiries or rights and permissions requests should be directed to the individual publisher as copyright holder.

BioOne sees sustainable scholarly publishing as an inherently collaborative enterprise connecting authors, nonprofit publishers, academic institutions, research libraries, and research funders in the common goal of maximizing access to critical research. 


\title{
A New Genus and Species of Blind Sleeper (Teleostei: Eleotridae) from Oaxaca, Mexico: First Obligate Cave Gobiiform in the Western Hemisphere
}

\author{
Stephen J. Walsh ${ }^{1}$ and Prosanta Chakrabarty ${ }^{2}$
}

\begin{abstract}
Caecieleotris morrisi, new genus and species of sleeper (family Eleotridae), is described from a submerged freshwater cave in a karst region of the northern portion of the State of Oaxaca, Mexico, Río Papaloapan drainage, Gulf of Mexico basin. The new species represents the first cave-adapted sleeper known from the Western Hemisphere and is one of only 13 stygobitic gobiiforms known worldwide, with all others limited in distribution to the Indo-Pacific region. The new taxon represents a third independent evolution of a hypogean lifestyle in sleepers, the others being two species of Oxyeleotris ( 0 . caeca and 0 . colasi) from New Guinea and a single species, Bostrychus microphthalmus, from Sulawesi. Caecieleotris morrisi, new species, is distinguished from epigean eleotrids of the Western Atlantic in lacking functional eyes and body pigmentation, as well as having other troglomorphic features. It shares convergent aspects of morphology with cave-dwelling species of Oxyeleotris and B. microphthalmus but differs from those taxa in lacking cephalic pores and head squamation, among other characters. Description of C. morrisi, new species, brings the total number of eleotrid species known from Mexico to 12. Seven of these, including the new species, occur on the Atlantic Slope.
\end{abstract}

Caecieleotris morrisi, género y especie nuevos de dormilón (familia Eleotridae), se describe de una cueva sumergida de agua dulce en una región kárstica del Estado de Oaxaca, México, cuenca del río Papaloapan, vertiente del Golfo de México. La nueva especie representa el primer eleótrido cavernícola del Hemisferio Occidental y es uno de los pocos gobiiform estigobiontes (sólo 13) conocidos mundialmente, todos los demás de distribución limitada a la región del Indo-Pacífico. El nuevo taxón representa la tercera evolución independiente del modo de vida hipógeo en los dormilones; los otros son dos especies de Oxyeleotris ( 0 . caeca y 0 . colasi) de Nueva Guinea y una sola especie, Bostrychus microphthalmus, de las islas Célebes (Sulawesi). Caecieleotris morrisi se distingue de los eleótridos epígeos del Atlántico occidental por la ausencia de ojos funcionales y de pigmentación en el cuerpo, así como por otras características troglomórficas. Comparte aspectos morfológicos convergentes con especies cavernícolas de Oxyeleotris y $B$. microphthalmus, pero difiere de éstas por la falta de poros cefálicos y escamación en la cabeza, entre otros caracteres. La descripción de C. morrisi lleva el número total de eleótridos conocidos de México a doce. Siete de estos, incluyendo la nueva especie, ocurre en drenajes del Atlántico.

C AVEFISHES have long been of keen interest to biologists interested in evolutionary forces that drive convergence of form and function in these uniquely derived organisms (e.g., Eigenmann, 1909; Poulson, 1963, 2001; Romero, 2001; Trajano et al., 2010). The most generalized and ubiquitous morphological features of troglomorphy, morphological features associated with subterranean life-loss or reduction of eyes, depigmentation, and the elaboration of non-optic sensory systems-are well documented for numerous species in diverse lineages. Extensive study of some taxa (e.g., Astyanax, Amblyopsidae) has led to their status as model organisms for many lines of investigation (e.g., Wilkens, 1988; Jeffery, 2001, 2009; Niemiller and Poulson, 2010; Protas and Jeffery, 2012; Soares and Niemiller, 2013), and the diversity of hypogean fishes and many aspects of their biology have been reviewed in a number of notable compilations (Thines, 1969; Weber et al., 1998; Weber, 2000; Romero, 2001; Romero and Poulson, 2001; Wilkens, 2005; Proudlove, 2006, 2010). In recent years there has been a surge in new discoveries and taxonomic descriptions of cavefishes as scientific exploration of subterranean habitats has increased, including many previously undocumented or unexplored systems (Pouyaud et al., 2012; Sparks and Chakrabarty, 2012; Larson et al., 2013; Chakrabarty et al., 2014), and as cryptic diversity is increasingly revealed through molecular work (Niemiller et al., 2012). This is particularly true of regions in the world rich in karst topography and where previous biospeleological exploration has only been comparatively recent, such as Southeast Asia (especially China), the Neotropics, and Madagascar.

On a global scale over 300 fish species have been reported to live or occur in caves and other subterranean habitats (Soares and Niemiller, 2013), about half of which are occasional or peripheral in occurrence. Time since divergence from surface-dwelling sighted ancestors is manifested among hypogean species by a gradation of morphological, physiological, behavioral, neurological, and other features. A limited number of those species reported from subterranean habitats are considered to be obligate cave species, i.e., living entirely in hypogean habitats, having obvious morphological adaptations to a cavernicolous life style and typically considered as troglobites, or, in terminology appropriately applied to aquatic taxa, stygobites. In contrast, troglophiles, trogloxenes, and accidentals are species that lack extreme morphological specialization, and, with the exception of some populations of the former, do not typically complete their life cycles in caves (see Discussion and references in Franz et al., 1994). About 170 species from 22 families and ten orders of stygobitic cavefishes are currently documented (Proudlove, 2010), whereas in the early 1990s only about 50 species were known (Allen, 1996). Each of the 22 families represents at least one evolutionary occurrence in cave habitats, and most of the families have several independent lineages. Most stygobitic fish taxa appear to have been derived from freshwater ancestors. Thus, apart from their obvious interest to scientists in many disciplines, including

\footnotetext{
${ }^{1}$ U.S. Geological Survey, 7920 NW 71 st Street, Gainesville, Florida 32653; Email: swalsh@usgs.gov. Send reprint requests to this address.

${ }^{2}$ Museum of Natural Science, Ichthyology Section, 119 Foster Hall, Department of Biological Sciences, Louisiana State University, Baton Rouge, Louisiana 70803; Email: prosanta@lsu.edu.
}

Submitted: 1 April 2015. Accepted: 24 September 2015. Associate Editor: T. J. Near.

(c) 2016 by the American Society of Ichthyologists and Herpetologists DOI: 10.1643/CI-15-275 Published online: 14 June 2016 
Table 1. Currently recognized stygobitic gobioid fish species of the world associated with freshwater, brackish, and marine (anchialine cave) habitats, excluding troglomorphic species with convergent morphology but associated with non-subterranean habitats (e.g., burrows, reefs, commensal species, and deep river channels; see Proudlove, 2006:appendix 3 for partial list, excluding deep-sea taxa).

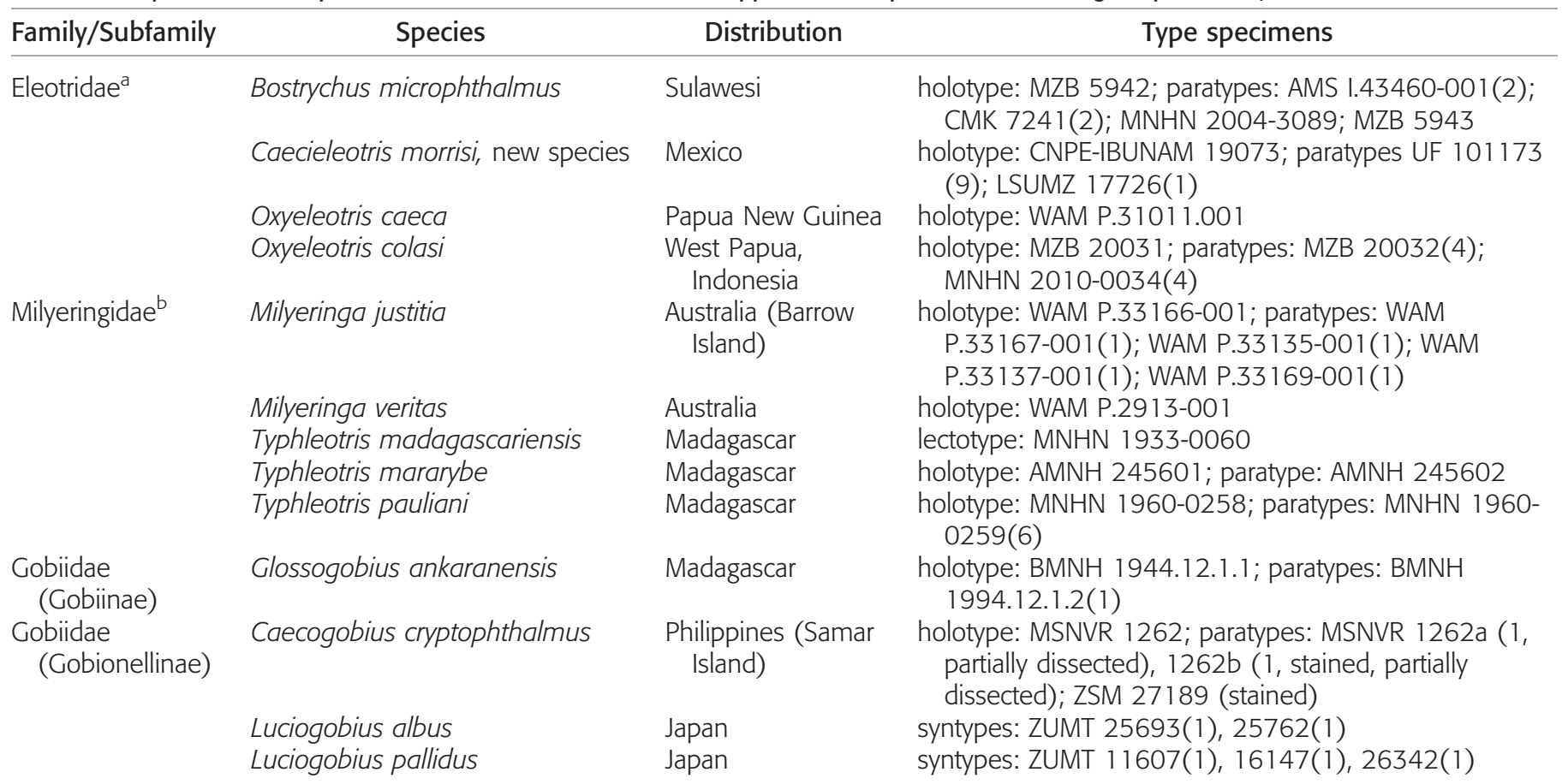

a An undescribed species provisionally assigned to Eleotris has been reported from Guam, Micronesia (Proudlove, 2010).

b Higher-group classification debated based on morphological and molecular analyses; some authors place within the Eleotridae (e.g., Larson et al., 2013; Eschmeyer and Fong, 2016). We recognize the family following Chakrabarty (2010), Chakrabarty et al. (2012), and Tornabene et al. (2013).

evolutionary biology, systematics, physiology, genetics, and functional morphology, cave-dwelling organisms also provide excellent subjects for examining ancient biogeographic disjunctions (Chakrabarty et al., 2012).

The order Gobiiformes, Percomorphacea (Betancur-R. et al., 2013; Thacker et al., 2015), is a widespread and morphologically diverse group $(>2,200$ species) that includes several blind, cave-adapted taxa. Previously described stygobitic gobiiforms are known exclusively from the Indo-Pacific region: Japan, Philippines, Indonesia, Sulawesi, Madagascar, Australia, and Papua New Guinea, with an unconfirmed species reported from the Micronesian island of Guam (Table 1). Nested within the gobiiforms are the sleepers, family Eleotridae, found worldwide throughout tropical and subtropical regions and primarily distributed in nearshore marine, brackish, and fresh waters. Three species of cave sleepers have been previously described, and an additional five species of the closely related family Milyeringidae are known. Herein, we describe the first species of stygobitic eleotrid known from the Western Hemisphere, a freshwater taxon from the State of Oaxaca, Mexico, and place it in its own genus, at present having no known affinity to other extant hypogean or epigean eleotrids.

\section{MATERIALS AND METHODS}

Measurements and meristic counts were taken following the general methods of Hubbs and Lagler (2004), with slight modifications and additions following Allen (1996), Pouyaud et al. (2012), Sparks and Chakrabarty (2012), and Larson et al. (2013) except as noted. Meristic counts and morphometric measurements were taken on the left side except where distortion or damage of a specimen required use of the right side for an individual count or distance. Point-to-point, straight-distance measurements were recorded to the nearest $0.1 \mathrm{~mm}$ using dial calipers or, in the case of short distances and small specimens, using an ocular micrometer fitted to a dissecting microscope calibrated with a stage micrometer. Pre-fin lengths were measured from the tip of the protruded lower lip to the base of each anterior fin ray or spine, or, in the case of the pectoral fin, to the anterior base of the expanded fleshy pad at the base of the fin. Head length (HL, in $\mathrm{mm}$ ) was measured from the tip of the lower lip to the upper attachment of the opercular membrane. Measurements are expressed as a percentage of standard length (SL, in $\mathrm{mm}$ ) or HL. All fin rays and spines were counted as separate elements, including the last two elements of the second dorsal and anal fins, where it was difficult to discern whether articulation was on a single or separate pterygiophore, from either radiographs or substage light transmission with a dissecting microscope of whole specimens. Vertebral counts were obtained from radiographs, are reported as total, and exclude the ural centrum. Principal (segmented) caudal rays included all rays directly articulating with the terminal edge of the hypural plate, as upper and lower on either side of the gap between the two parts of the hypural. Procurrent rays included all other unsegmented rays in each lobe; however, caudal fins were generally frayed and segmentation was difficult to discern, so recorded counts are provisional. A single specimen of the type series (UF 101173; $28.2 \mathrm{~mm} \mathrm{SL}$ ) was cleared and stained (CS) following the procedure of Potthoff (1984) to confirm anatomical details. Neither the CS specimen or radiographs permitted detailed study of osteology. Institutional abbreviations follow Sabaj Pérez (2014). 


\section{Caecieleotris, new genus}

urn:Isid:zoobank.org:act:B0626A75-66BC-4F7E-A427B092870D954F

Type species.-Caecieleotris morrisi, new species, by monotypy and original designation.

Diagnosis.-Caecieleotris is a blind, freshwater, hypogean eleotrid that is distinguished from the majority of other sleepers, and all epigean forms in the Western Atlantic, by the absence of eyes and pigmentation. Caecieleotris is provisionally placed in the Gobiiformes, family Eleotridae, on the basis of a limited number of characters that it shares with other members of the family as currently recognized, e.g., having a mode of six branchiostegals, pelvic fins separated at the base, and procurrent cartilages of the caudal fin elongated posteriorly and extended over the epurals (see Discussion). Caecieleotris differs from the cave-dwelling Bostrychus microphthalmus of Sulawesi in the absence of eyes (versus present, minute, covered by skin), complete lack of pigmentation (versus body pale, few melanophores on dorsum), lack of scales on operculum and side of head (versus present), lower lateral scale count ( $\leq 32$ versus $\geq 102$ ), fewer transverse scale rows on midside of body ( $\leq 6$ versus $\geq 31$ ), and absence of pores associated with the cephalic lateralis system (versus present). Caecieleotris can be distinguished from the blind species of Oxyeleotris of Indonesia (O. colasi) and Papua New Guinea (O. caeca) in lacking sensory pores on the head associated with the cephalic lateralis system (versus cephalic sensory pores present, although reduced in comparison to other gobiiform fishes). Caecieleotris can be distinguished from the cave species of Typhleotris from Madagascar (T. madagascariensis, T. mararybe, and $T$. pauliani) in having the head asquamate (versus scales extending anteriorly onto the head), squamation absent on the venter (versus fully scaled on the belly as well as laterally below the pectoral fin), scales embedded (especially on anterior half of body) and hard to discern (versus in prominent rows on the surface of the body and head). Species of the western Australian cave-dwelling Milyeringa have elements of the first dorsal fin reduced (spines II-IV; $M$. veritas) to absent ( $M$. justitia), versus V-VI in Caecieleotris. Species of Milyeringa also have 4-5 total lepidotrichia (first unsegmented) in the pelvic fin versus six in Caecieleotris.

Etymology.-Caeci from the Latin meaning blind, and eleotris, referring to the common and widespread type genus of Eleotridae.

Remarks.-Discovery of C. morrisi, new species, represents only the fourth known hypogean species of Eleotridae, and it appears to be an independent evolutionary derivation given the extremely disjunct geography between it and other cavedwelling eleotrids. Moreover, it differs from extant epigean eleotrids in the Western Atlantic and Eastern Pacific (i.e., species of Dormitator, Eleotris, Erotelis, Gobiomorus, and Guavina) by its pronounced troglomorphic features. The separate pelvic fins and general body shape are characteristic of species of Eleotridae and readily distinguish C. morrisi, new species, from the many genera and species of Western Atlantic gobies (see Murdy and Hoese, 2002) that occur in proximity to its range, most of which are marine in distribution. In addition to the independently derived Indo-Pacific cave eleotrids, the eleotrid-like Milyeringidae also includes cave-inhabiting species of the Malagasy and
Australian genera Typhleotris and Milyeringa, but none of these taxa are considered to be related to $C$. morrisi, new species. All of these cave taxa share certain morphological features but also vary in the degree to which they exhibit extreme troglomorphic features (see Discussion).

\section{Caecieleotris morrisi, new species}

urn:Isid:zoobank.org:act:193B8DF5-31BD-4BE6-AAD534A6DF872681

Oaxaca Cave Sleeper, Guavina Cueva de Oaxaca

Figures 1, 2, 3; Table 2

Holotype.-CNPE-IBUNAM 19073 (ex. UF 101173), $34.1 \mathrm{~mm}$ SL, Mexico, Oaxaca State, submerged cave at the bottom of Presa Miguel Alemán reservoir, approximately $18^{\circ} 11^{\prime} 22.58^{\prime \prime} \mathrm{N}, 96^{\circ} 36^{\prime} 56.02^{\prime \prime} \mathrm{W}, 16$ April 1995, T. L. Morris.

Paratypes.-LSUMZ 17726 (ex UF 101173), 1, 28.0 mm SL; UF 101173, 9, 11.6-31.6 mm SL (1 CS, 28.2 mm SL); UMMZ $231174,2,19.3-29.9 \mathrm{~mm}$ SL. Same locality and date as the holotype.

Diagnosis.- Species diagnosis is that of the monotypic genus, with character states of Caecieleotris as stated above.

Description.-Selected proportional measurements presented in Table 2. A diminutive, anophthalmic, unpigmented eleotrid. Size range of type specimens 11.6-34.1 mm SL. Body slender, relatively elongate, laterally compressed, body depth at pelvic-fin origin 14.2-18.6\% SL (Fig. 1A). Body width at pectoral-fin origin $11.6-17.4 \%$ SL. Head broad and moderately depressed, shovel-shaped, head width 54.1$68.2 \%$ HL. Snout prominently upturned. Dorsal profile of head straight to weakly concave. Ventral profile of head weakly convex. Dorsal and ventral profiles of body posterior to pectoral fins gradually tapered, nearly symmetrical except for position of median fins, body depth only slightly reduced from pectoral-fin insertion to anal-fin origin. Caudal peduncle relatively shallow (depth 7.4-8.4\% SL) and narrow (width $2.9-5.4 \% \mathrm{SL}$ ). Deep fleshy groove on ventral side of body from pectoral-fin insertion to anal-fin origin, with a keel-like midventral flap of skin, possibly representing artifact of shrinkage following preservation or presence of little or no food in the gut of individuals when preserved.

Meristic characters exclude data for the two smallest, presumably juvenile, paratypes (UF 101173; 11.6-11.9 mm SL) and include only partial data for two other paratypes (UMMZ 231174). Values for holotype indicated by asterisk, number of specimens parenthetically as follows. First dorsalfin elements modally VI: V (5), VI* (6); spines thin, flexible. Second dorsal-fin elements modally I,7: I,7* (6), I,8 (5). Analfin ray elements modally I,8: I,6 (1), I,7 (2), I,8* (6), I,9 (1), I,10 (1). Pelvic-fin elements I,5* (11). Spines in second dorsal, anal, and pelvic fins feeble, thin, flexible. Pectoral-fin rays modally 14: 13 (4), 14 (6), 15* (1). Upper principal (segmented) caudal-fin rays modally 6: 5 (1), 6* (7), 7 (3). Lower principal caudal-fin rays modally 6: 5* (4), 6 (5), 7 (2). Upper procurrent caudal-fin rays modally 8: 5 (1), 6 (3), 7 (2), $8^{*}(5)$. Branchiostegals modally 6: 4 (1), 5 (1), 6* (9). Scales in lateral series modally 27: 25 (2), 26 (1), 27 (3), 28* (1), 31 (2), 32 (1). Scales on body cycloid, large (5-6 transverse scales on midside of body), imbricate, thin, tightly appressed to body. Circumferential caudal peduncle scales modally 10: 10* (6), 
A

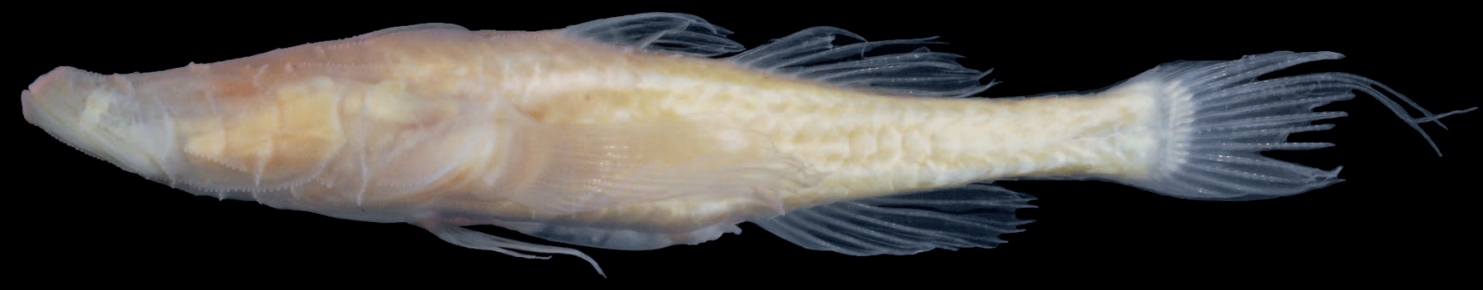

B
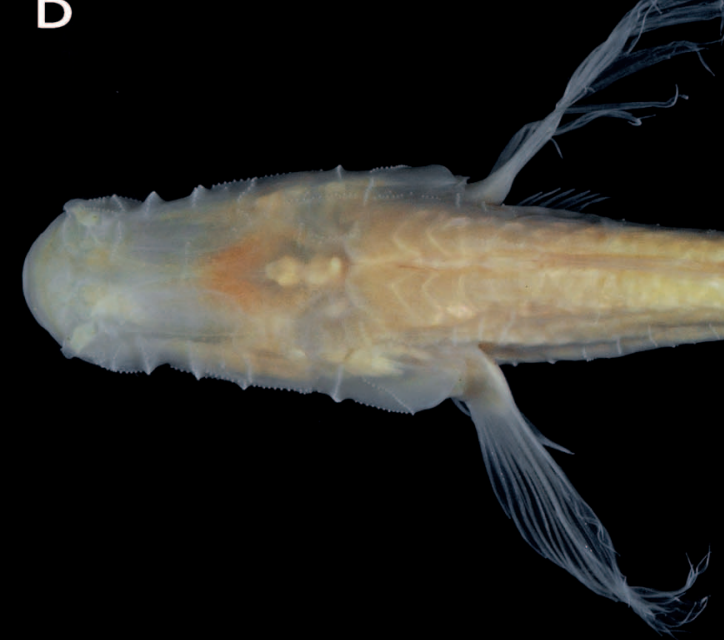

C
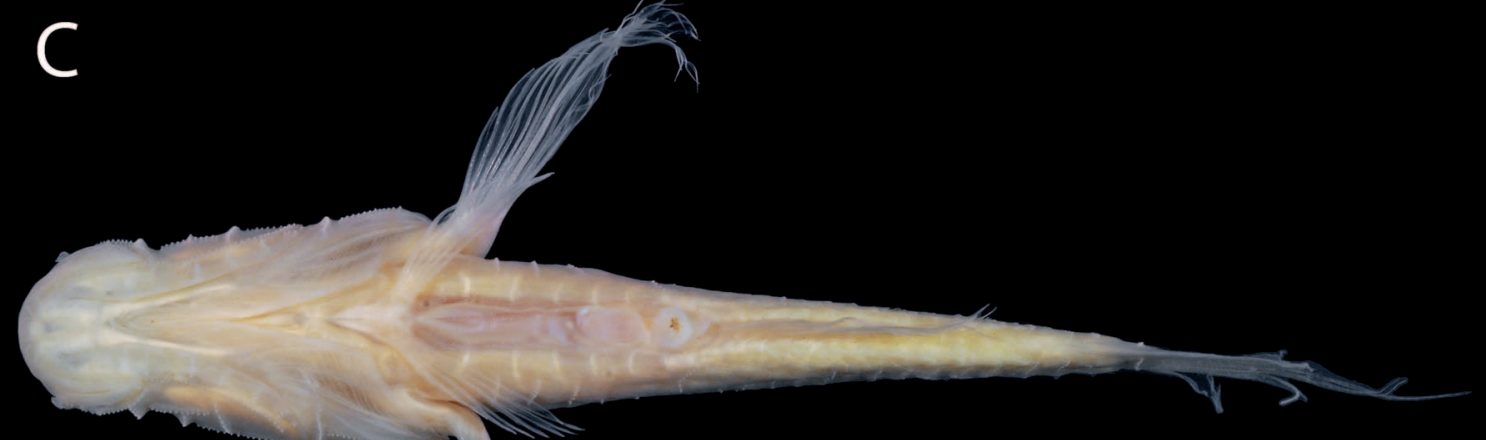

rem inste
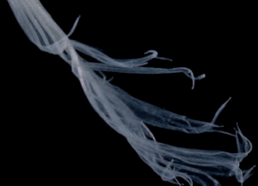

Fig. 1. Holotype of Caecieleotris morrisi, CNPE-IBUNAM 19073, $34.1 \mathrm{~mm} \mathrm{SL}$, sex undetermined, in lateral (A), dorsal (B), and ventral (C) views. 

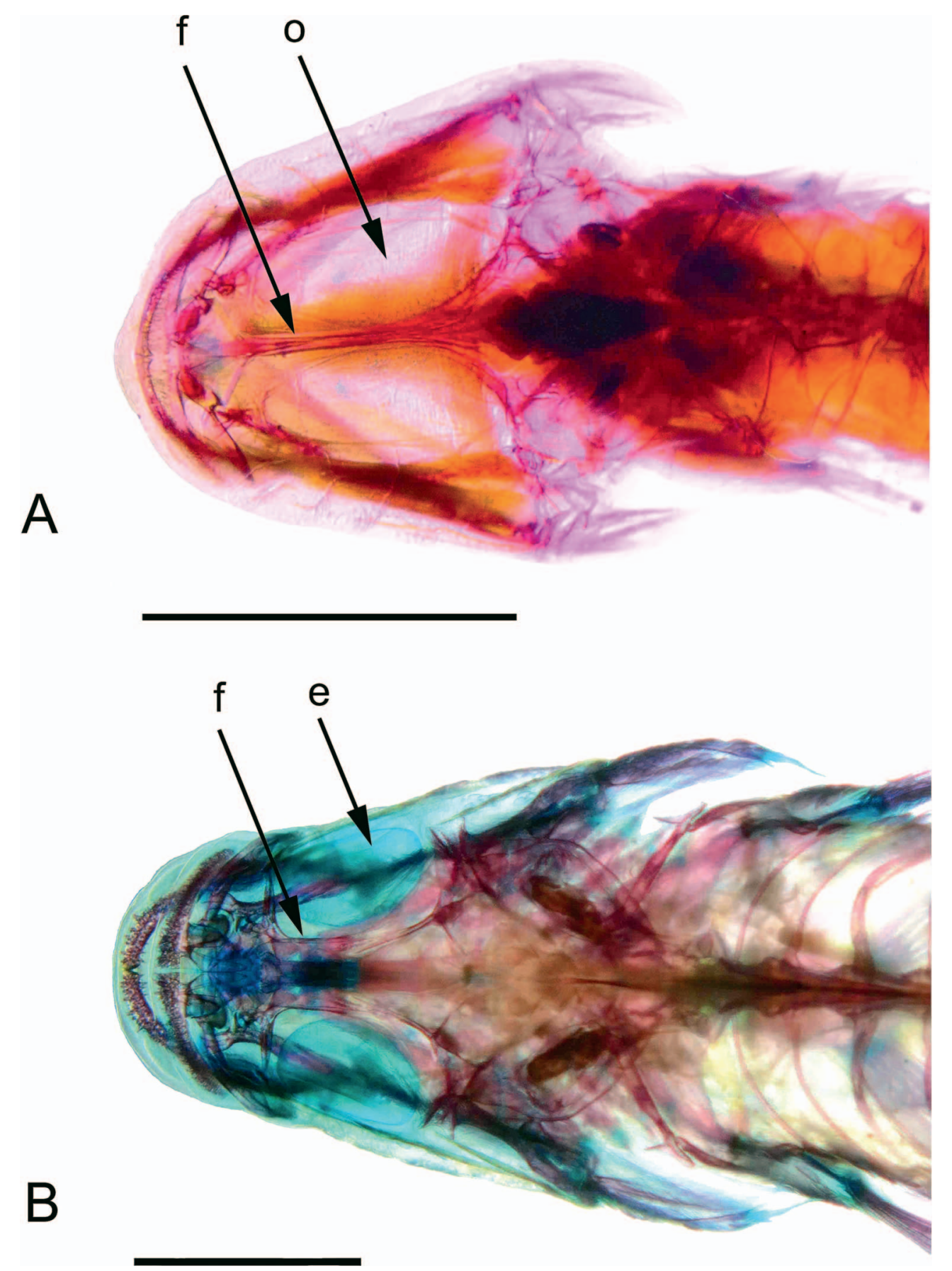

Fig. 2. Neurocranium in dorsal view of (A) Caecieleotris morrisi (UF 101173, paratype) and (B) Eleotris perniger (UF 27603). Abbreviations: e, eye; $f$, frontal; o, anophthalmic orbital region, illustrating thin, rod-like ossification in (A) in comparison to broad, laminar shelf in (B). Scale bars = $5 \mathrm{~mm}$.

11 (4). Total vertebrae modally $24: 24^{*}(6), 25$ (3). Rib pairs modally 6: 6 (4), $8^{*}(2)$.

Head large, its length $29.2-42.5 \%$ SL. Dorsum of snout at midline forming a small raised bump, extending posteriorly a short distance along midline as a weakly ossified ridge. Snout broadly crescentic in dorsal view (Fig. 1B). Mouth large, superior, length of both jaws about one-third HL; mouth distinctly upturned, midline of lower jaw projecting anterior to midline of upper jaw. Posterior edges of jaws curved gently inward in ventral view (Fig. 1C). Lips relatively thin, prominent groove between upper lip and anterodorsal part of head, frenum present at midline. Basihyal reaching to approximately midway between tip of snout and rear margin of jaw. Teeth in upper and lower jaw conical, slender, sharp, uniform in size, slightly recurved inward, in 1-3 irregular rows. Gill rakers short, blunt, denticulate at terminal end; gill filaments also short, about 3-4 times length of rakers. Nares large and prominent, anterior naris a broad tube extending above upper lip and angled forward about $45^{\circ}$ from sagittal plane of head, with thin fleshy flap surrounding oval opening. Posterior naris a large, oval to circular, dorsaloriented opening lacking marginal flap. Nasal rosette and broad tubular connection between anterior and posterior nares readily visible through unpigmented skin. Brain visible beneath skin on top of head, detailed structure not readily visible eternally, but olfactory lobes, cerebellum, and hindbrain evident; optic lobes presumed reduced. Olfactory nerve well developed. Narrow posterior process of mesethmoid and lateral ethmoid articulating with long, closely apposed frontals, together forming a narrow median keel-like ossifi- 
A
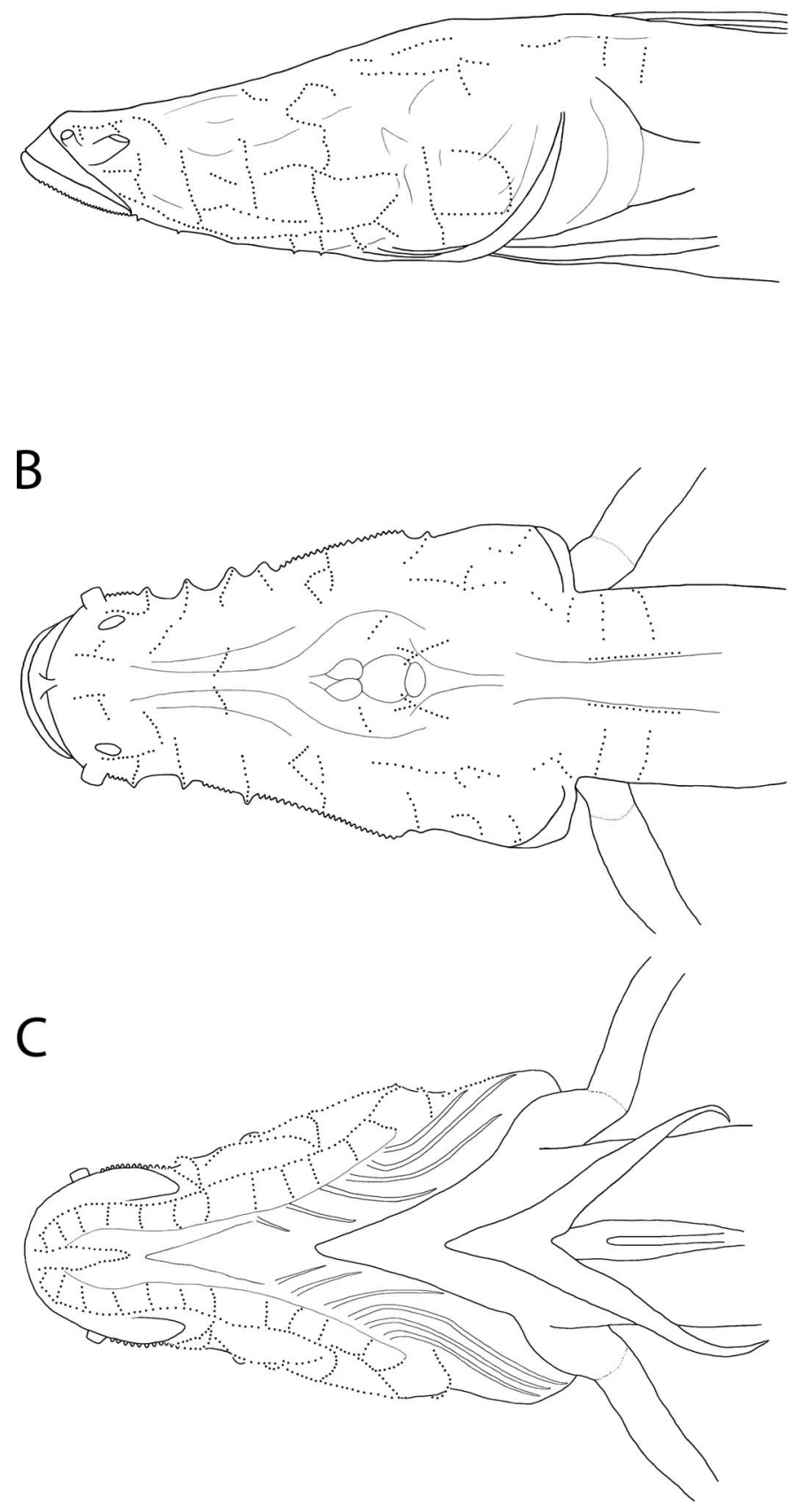

Fig. 3. Pattern of sensory head papillae series on head of Caecieleotris morrisi, drawn from composite of UF 101173 (31.6 mm SL, paratype) and CNPE-IBUNAM 19073 (34.1 mm SL, holotype) in lateral (A), dorsal $(B)$, and ventral (C) views. Dorsal fin omitted from (B). Scale bar $=5$ $\mathrm{mm}$.

cation connecting the upper jaw bones with the rear of the skull (Fig. 2A), much thinner than in Eleotris (Fig. 2B). Large oval foramen on dorsum of head in anophthalmic orbital region (Fig. 2A), on each side of longitudinal midline, formed in unossified area surrounded by jaw apparatus anteriorly, frontals medially, suspensorium posteriorly and ventrolaterally, overlain by thin opaque yellow musculature and integument. No eyes visible externally in most specimens, but some individuals with a minute spherical black lens located on either side dorsally just below the epidermis, slightly medial to point midway between side of head and center of frontal, at a longitudinal distance of about onethird from tip of the snout to posterior margin of opercle. Opercular openings large, thin opercular membranes nearly separate, only narrowly joined anteroventrally to isthmus. Posteriorly, opercular membrane attached to body anterodorsal to pectoral-fin origin. Branchiostegals acicular, flexible; anterior 1-2 shortest, posterior-most 3-4 longer, gently curved dorsolaterally.

Lateral line and cephalic pores absent. Head and body with profuse distribution of sensory papillae in discrete vertical, transverse, horizontal, and oblique rows. The head papillae pattern is essentially the transverse type following the nomenclature of Hoese (1983), but it is unknown if individual lines of papillae are homologous with numbered series as described for many other gobiiforms. The following description is based on a specimen illustrated in Figure 3 and the holotype (Fig. 1). Sensory papillae system forming marked relief on dorsolateral aspect of snout and anterior portion of head, with rows of papillae developed on prominent fleshy ridges; $3-5$ ridges in preorbital region with papillae elevated on each ridge in a semicircular pattern from the dorsolateral edge of the head extending around to the ventrolateral aspect of the chin (Fig. 3A), with an additional dorso-ventral oriented ridge of papillae in an approximately sagittal plane nearly equal to or just behind the posterior margin of the brain (Fig. 3B). Top of snout with a short longitudinal series of papillae on each side extending from a plane just in front of the anterior naris to a plane approaching the rear margin of the posterior naris, and another short row of papillae distributed laterally and obliquely from each longitudinal series toward the posterior naris. A parallel, oblique row of papillae posterior to the latter, extending from the mid-dorsal to lateral preorbital region of the head. Three irregular horizontal series of papillae on the ventrolateral side of the head, the top two broken, the lower continuous from the posterior margin of the jaw to above the origin of the preopercle and posteriormost branchiostegals; the uppermost of these may correspond to the upper horizontal line (LTU) and the lower to the lower horizontal line (LTB) as described by Hoese (1983). Five vertical rows of papillae on the ventrolateral side of the head distributed from posterior edge of the jaw to anterior edge of the opercle, apparently corresponding to vertical transverse lines (VT) of Hoese (1983). Lateral margin of opercle with a semicircular pattern of papillae in a continuous dorsolateral, vertical, and ventrolateral row. Posterior half of top of head with single longitudinal row and irregular, transverse or obliquely directed papillae distributed mid-medially, posterolateral to brain, and dorsally above each opercle. Preopercular mandibular series consisting of multiple lines of transverse papillae medial to longitudinal line extending from near anterior end of lower jaw to lateral opercular margin (Fig. 3C). Two dorsolateral rows of papillae, one above and the other just posterior to base of pectoral fin. Single longitudinal row of papillae on each side of middorsal ridge above and just posterior to base of pectoral fin. About five vertical to transverse rows of papillae extending from midlateral region of each side to ventromedial region of abdomen distributed approximately equally between pectoral-fin insertion and urogenital papilla. Additional irregularly spaced vertical rows of papillae distributed along sides of body from plane passing through second dorsal and anal fins to caudal peduncle. 
Table 2. Measurements and meristic counts of type specimens $(n=11)$ of Caecieleotris morrisi. Range, mean, and standard deviation (SD) of measurements include values for the holotype.

\begin{tabular}{|c|c|c|c|c|}
\hline \multicolumn{5}{|c|}{ Holotype } \\
\hline & CNPE-IBUNAM 19073 & Range & Mean & SD \\
\hline Standard length (SL, mm) & 34.1 & $19.3-34.1$ & 27.0 & 4.9 \\
\hline Head length (HL) & 34.4 & $29.2-42.5$ & 35.6 & 3.2 \\
\hline Pre anal-fin length & 60.1 & $56.5-67.8$ & 62.4 & 3.5 \\
\hline Pre spinous-dorsal fin length & 45.5 & $42.7-50.0$ & 46.1 & 2.0 \\
\hline Pre pectoral-fin length & 29.3 & $28.8-35.6$ & 31.1 & 2.1 \\
\hline Pectoral-fin origin to spinous dorsal-fin origin & 8.0 & $7.8-11.8$ & 9.4 & 1.1 \\
\hline Body depth at pelvic-fin origin & 17.6 & $14.2-18.6$ & 16.4 & 1.6 \\
\hline Caudal peduncle depth & 7.8 & 7.4-8.4 & 7.9 & 0.3 \\
\hline Caudal peduncle length & 17.6 & $17.6-28.4$ & 24.3 & 3.5 \\
\hline Anal-fin base length & 13.5 & $11.4-19.8$ & 14.7 & 2.8 \\
\hline Spinous dorsal-fin base length & 9.4 & $6.7-13.4$ & 9.9 & 2.0 \\
\hline Rayed dorsal-fin base length & 15.0 & $7.4-18.2$ & 14.7 & 2.8 \\
\hline \multicolumn{5}{|l|}{ Percent HL } \\
\hline Head width & 63.4 & $54.1-68.2$ & 62.7 & 4.9 \\
\hline Upper jaw length & 36.1 & $27.0-40.9$ & 31.2 & 4.2 \\
\hline Lower jaw length & 37.4 & $28.1-45.5$ & 33.1 & 5.0 \\
\hline
\end{tabular}

First dorsal-fin origin anterior to midpoint of body and vertical through tip of adducted pelvic rays, pre-spinousdorsal fin length $42.7-50.0 \%$ SL, base of fin $6.7-13.4 \%$ SL. Origin of second dorsal fin about equal with or slightly posterior to vertical plane passing through urogenital papilla, slightly anterior to origin of anal fin. Base of second dorsal fin $7.4-18.2 \%$ SL, longer than that of spinous dorsal but less than anal-fin base length. Both second dorsal and anal fins high, sinuous, broadly rounded, middle branched rays longest. Anal fin long, base length 11.4-19.8\% SL, origin slightly posterior to urogenital papilla, insertion slightly posterior to that of second dorsal fin. Caudal fin pointed to lanceolate, middle rays longest (sometimes considerably longer than others), terminal ends of rays frayed in some specimens (see Fig. 1A; in comparison, species of Dormitator have a broadly rounded fin, and species of Eleotris, Gobiomorus, and Guavina have a semi-truncate to rounded fin). Bases of pelvic fins apposed but fins separate (as in other eleotrids, compared to fused in most gobiids), jugular, anterior to plane passing through origin of pectoral-fin rays but about equal with anterior edge of thick anteromedial pectoral-fin musculature, posterior to symphysis of opercular membranes. Pelvic fin relatively long and ribbon-like, pointed, middle to posterior branched rays longest, tip of appressed fin not reaching to genital papilla. Pectoral-fin base obliquely vertical, origin (dorsal edge) slightly posterior to insertion (ventral edge), basal portion surrounding proximal radials projecting from body as fleshy appendage. Pectoral fins elongate and produced with filamentous rays, most pronounced in larger individuals, middle branched rays longest, tips of appressed fins reaching well posterior to anal-fin origin.

Coloration in preservative.-Head and body without pigmentation, uniformly white to yellowish and opaque in appear- ance. Fins translucent or transparent. Internal organs and musculature yellowish to amber; muscle bands evident where not obscured by squamation.

Etymology.-The specific epithet is a patronym to honor our good friend and colleague Thomas L. Morris, discoverer and collector of this new species, renowned cave diver and speleobiologist, intrepid explorer, and respected conservationist devoted to the protection of karst habitats and their associated biotas.

Distribution and habitat.-Caecieleotris morrisi is currently known from only a single cave system beneath Presa Miguel Alemán reservoir, northern State of Oaxaca, Mexico, located along the east side of the Sierra Mazateca front range (Fig. 4). The lake is sometimes also referred to as Temascal, name of an adjacent municipality (also known as Nuevo Soyaltepec) and associated hydroelectric plant. This artificial impoundment was created following the construction of Presa (=dam) Miguel Alemán, a large dam on the Tonto River, major headwater tributary of the Río Papaloapan draining into the southwestern Gulf of Mexico. Construction of the dam began in 1949 and filling of the reservoir was completed in 1955. The $830 \mathrm{~m}(2,723 \mathrm{ft})$ long dam and 9,300 $\mathrm{km}^{2}(3,591$ $\mathrm{mi}^{2}$ ) reservoir provides hydroelectricity, flood control, and irrigation supply. The dam is operated in conjunction with the Cerro do Oro Dam (and associated $220 \mathrm{~km}^{2}, 85 \mathrm{mi}^{2}$ reservoir) located on the Santo Domingo River, which is joined to Presa Miguel Alemán reservoir by a short, narrow channel. The Tonto and Santo Domingo rivers join to the south of the city of San Juan Bautista Tuxtepec to form the Río Papaloapan, Mexico's second largest river (mean annual discharge $3.73 \times 10^{4} \mathrm{~m}^{3}$; Miller et al., 2005).

The cave entrance at the type locality lies at a depth of about $6.1 \mathrm{~m}(20 \mathrm{ft})$ beneath a rocky bluff along the shoreline 


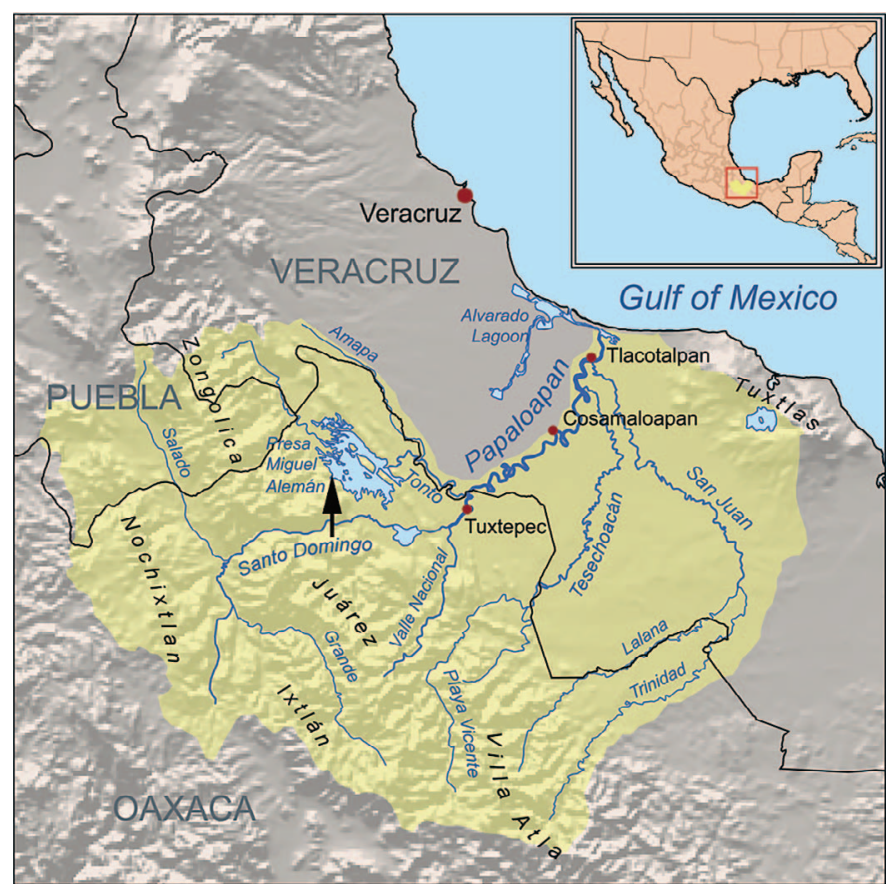

Fig. 4. Map of Presa Miguel Alemán and vicinity, Oaxaca, Mexico, type locality (vertical arrow) of Caecieleotris morrisi. Source: Wikimedia Commons (http://en.wikipedia.org/wiki/File:Papaloapanrivermap. png).

of the lake. Immediately within the cave, the depth descends to about $27.4 \mathrm{~m}(90 \mathrm{ft})$ before rising to a depth of about 12.2 $\mathrm{m}(40 \mathrm{ft})$ where it then levels off. Divers with the collecting party observed flowstone in the cave (sheet-like mineral deposits typically composed of calcite). This suggests that prior to impoundment the entrance might have been a highwater, wet season overflow, and that a lower (now deeper) entrance might exist that could have been a perennial artesian spring in pre-reservoir conditions (Tom Morris, pers. comm.). In addition to this cave the dive team explored a submerged sulfur spring nearby where, as expected, no higher taxa were observed.

Conservation status.-All cavefish species of North America are in some level of jeopardy due to endemic distributions and the vulnerability of subterranean habitats to land-use changes and environmental perturbations (Jelks et al., 2008), as is the general case with cavefishes globally (Proudlove, 2001, 2006). Higher taxonomic groups (genera and families) with obligate cave-dwelling species have disproportionately high levels of imperilment in comparison to groups comprised primarily of epigean forms. Stygobitic ictalurids (Prietella lundbergi, P. phreatophila, Satan eurystomus, and Trogloglanis pattersoni) are considered endangered, and the number of at-risk species in other families is high relative to the total number of taxa in each group or the number distributed in North America: a single species (Typhliasina pearsei) of Bythitidae (100\%), the Amblyopsidae (6 of 7 species, 86\%; although Typhlichthys represents a species complex according to Niemiller et al., 2012), and the Heptapteridae (6 of 9, 67\%; Jelks et al., 2008; Chakrabarty et al., 2014). Insofar as C. morrisi is presently known only from the type series collected over two decades ago and nothing is known regarding distribution or population abundance, it is strictly conjecture to speculate about conservation status of the species. However, there have been extensive hydrologic modifications in the region of the type locality, and the biologically rich State of Oaxaca has undergone extensive land-use changes over the last few decades. These changes include widespread deforestation (Velázquez et al., 2003) that is projected to continue into the future (Gómez-Mendoza et al., 2006), one of many factors known to degrade and threaten subterranean habitats (Bichuette and Trajano, 2010). Within central Mexico many endemic fishes are considered imperiled (Dzul-Caamal et al., 2012). Given current and projected land-use conditions, it may be prudent for the Mexican government to consider protective status for $C$. morrisi under the Norma Oficial Mexicana (NOM; SEMARNAT, 2010), pending further exploration and studies to evaluate population status, distribution, and ecology of this unique species.

\section{DISCUSSION}

The Gobiiformes is diagnosed by at least 14 putative synapomorphies (Wiley and Johnson, 2010) identified from among a broad suite of osteological and myological characters that have been extensively examined by various investigators in efforts to determine relationships within this species-rich order as well as to explore possible relationships of the Gobiiformes with other percomorph groups (e.g., Springer, 1983; Hoese and Gill, 1993; Johnson and Brothers, 1993; Winterbottom, 1993; Thacker, 2009; Gill and Mooi, 2012). A comprehensive morphological analysis of C. morrisi is beyond the scope of the present study. Furthermore, suboptimal quality of the only cleared-and-stained specimen (CS; $28.2 \mathrm{~mm}$ SL, presumably a juvenile or subadult) and lack of specimens exhibiting a complete series of ontogenetic stages precludes a detailed evaluation of many of these characters. Nevertheless, certain character states observed in the CS specimen confirm that the new taxon is a gobiiform: pelvic intercleithral cartilage is present; ventral intercleithral cartilage is present; hypurals 1 and 2 are fused; hypurals 3 and 4 are fused to each other and to the urostyle; the dorsalmost pectoral ray articulates with the posterior margin of the dorsal-most actinost and lacks a medial enlarged articular base; infraorbital bones consist of paired lacrimals and the second element is apparently reduced or absent; supraneurals are absent; and sensory papillae are distributed extensively on the head and body.

Placement of $C$. morrisi in the Eleotridae is provisional on the basis of a limited number of readily observable characters. Monophyly of the family as currently recognized is questionable, and the group is generally defined by plesiomorphic rather than derived characters (Hoese, 1984; Thacker, 2009). Typically, species of Eleotridae, Butidae, Rhyacichthyidae, and Odontobutidae are separated from the Gobiidae and Gobionellidae in having six (versus five) branchiostegal rays (Hoese, 1984; Hoese and Gill, 1993; Thacker, 2011; Gill and Mooi, 2012). Specimens of the type series of C. morrisi exhibit unusual variation of 4-6 (modally 6) branchiostegals, with an asymmetrical number on each side in at least one individual; the small anterior elements are difficult to discern in alcohol-preserved specimens, but a reduced number may be related to developmental truncation as a result of extreme troglomorphy. As in most other eleotrids, C. morrisi also has separate pelvic fins, unlike the majority of other gobiiforms. Also, as is characteristic of other eleotrids (Hoese and Gill, 1993), C. morrisi appears to have procurrent cartilages of the caudal fin elongated posteriorly and extended over the 
anterior epural(s). Unusual variation observed in some meristic and mensural characters of the type series may be attributable, in part, to developmental truncation as result of troglomorphy, contortion of preserved specimens, inaccurate counts or measurements (difficult given the lack of pigmentation and small body size), or a combination of factors.

The discovery of $C$. morrisi brings to 13 the number of described stygobitic gobiiforms worldwide, and to four the number of Eleotridae, with an additional undescribed cave sleeper reported from Guam (Table 1). Most notably, $C$. morrisi represents the only cave-adapted sleeper known from Atlantic Ocean drainages, with all others confined to the Indo-Pacific region. Two of the four described cave sleepers (Oxyeleotris caeca and O. colasi) occur on the island of New Guinea and are thought to be related to each other, as well as to $O$. fimbriata, an epigean species that is distributed widely in New Guinea and northern Australia (Allen, 1996). There is also molecular evidence supporting monophyly of $O$. colasi with the epigean $O$. marmorata (type species of the genus) and $O$. lineolata, in a phylogenetic analysis that included eight other Indo-Pacific and eastern Atlantic gobiiforms (Pouyaud et al., 2012). Bostrychus microphthalmus is a cave eleotrid from Sulawesi that appears to be most similar morphologically to $B$. sinensis, a wide-ranging tropical IndoPacific species that most commonly occurs in mangroves and estuaries, and occasionally enters fresh water, along with other congeners that occur in or are confined to fresh waters (Hoese and Kottelat, 2005). In the molecular analysis by Pouyaud et al. (2012), B. sinensis appears as the sister taxon to the monophyletic Oxyeleotris. Other molecular phylogenetic studies have demonstrated that cave gudgeons of the genus Typhleotris (T. madagascariensis, T. mararybe, and T. pauliani), endemic to karst systems in southwestern Madagascar, are the sister group to Milyeringa (M. justitia and M. veritas), endemic to similar cave habitats in northwestern Australia (Chakrabarty et al., 2012). The phylogenetic position of Milyeringa within the Gobiiformes has been questioned (reviewed by Larson et al., 2013), and some authors place the genus in the Eleotridae (references in Table 1 footnote), but the nuclear DNA evidence suggests a distinct relationship with eleotrids and supports recognition of the group at the family level, Milyeringidae (Tornabene et al., 2013; Thacker et al., 2015). We should note that attempts to extract and amplify DNA from specimens of C. morrisi failed, possibly due to exposure to formalin at some stage of preservation.

The aforementioned cave-adapted species share convergent characters that are common to stygobitic fishes and that are the subject of extensive study, i.e., loss or reduction of eyes and pigmentation, hyper-development of non-optic sensory systems, and other morphological features associated with a hypogean lifestyle. Among the cave-dwelling eleotrids and milyeringids there is a gradation of these morphological characters (see Diagnosis), suggesting that considerable differences exist between taxa based on divergence times from ancestral lineages and concomitant time that selective forces have been acting during cave existence. Indeed, a remarkable ancient sister-group relationship and the widely disjunct Malagasy-Australian distribution of the milyeringids reveals the historical extent to which individual lineages may be subjected to similar evolutionary processes acting independently in the hypogean environment (Chakrabarty et al., 2012).

The pronounced troglomorphic features of C. morrisi, namely the near complete loss of eyes, absence of all pigmentation, and well-developed neuromast/sensory papil- lae system suggest that this species has an ancient history of living in darkness. Based on geography alone, it is unlikely that C. morrisi shares a close relationship with other described cave gobiiforms. It is most parsimonious to infer that $C$. morrisi shares a common ancestral lineage with one or more species of extant eleotrids in the westcentral Atlantic, particularly those species ranging in the Gulf of Mexico and western Caribbean, but gross morphological features do not provide insight into possible relationships. However, biogeographical patterns from multiple taxonomic groups provide evidence of historical linkages between freshwater faunas of the Río Papaloapan drainage and the Central American/ Neotropical realm (Huidobro et al., 2006; Quiroz-Martinez et al., 2014). The Río Papaloapan is part of the PapaloapanCoatzacoalcos division of the Usumacinta ichthyofaunal province (Miller et al., 2005). Within this major province fish diversity is great, with over 200 described species, over half of which are restricted to fresh waters; of those permanent freshwater species, at least 18 are thought to be derived from marine ancestors. About one quarter of the Río Papaloapan ichthyofauna is endemic, including two species of cave hepapterids (Rhamdia reddelli and $R$. zongolicensis). Moreover, considered in its entirety, the Usumacinta ichthyofaunal province is occupied largely by taxa of Middle or South American derivation (Miller et al., 2005; Matamoros et al., 2015). Thus, possible phylogenetic affinities of C. morrisi with taxa outside of the Gulf of Mexico or circum-Caribbean region cannot be precluded.

Mexico has six extant, epigean eleotrid species in Gulf Coast drainages: Dormitator maculatus, Eleotris amblyopsis, Eleotris perniger, Erotelis smaragdus, Gobiomorus dormitor, and Guavina guavina (Castro-Aquirre et al., 1999; Miller et al., 2005). An additional five eleotrid species occur on the Pacific Slope of Mexico: Dormitator latifrons, Eleotris picta, Erotelis armiger, Gobiomorus maculatus, and Gobiomorus polylepis. Caecieleotris morrisi exhibits a generalized eleotrid shape with a depressed head and elongate, slightly compressed body, and perhaps is most similar in shape to species of Eleotris and Erotelis. However, the very large spatulate-shaped head of $C$. morrisi is more typical of some of the other cave gobiiforms and is especially similar to that of Oxyeleotris (see Allen, 1996:fig. 3; Pouyaud et al., 2012:figs. 2-3), most likely relating to convergence in these cave obligates. Future study may not only be informative in determining the phylogenetic relationship of $C$. morrisi with other Atlantic or Pacific eleotrids, but could provide interesting clues about biogeography, as well as placing into an evolutionary context information gleaned about convergence in morphology and other aspects of the biology of cave-adapted sleepers.

The discovery of $C$. morrisi in southcentral Mexico is not surprising given the number of endemic hypogean species of other freshwater taxa in the region and the many stygobitic fishes documented elsewhere in Mexico (Hubbs, 1938) and karst regions of the eastern and central United States, Caribbean, and Neotropics (Proudlove, 2006). Central Mexico has a notable subterranean invertebrate fauna, especially decapod crustaceans that have invaded cave systems independently and that are thought to have been derived from surface or marine ancestors with affinities to cavernicolous species in the United States, Central America, and the western Caribbean region (Hobbs et al., 1977; Hobbs, 1994; Hobbs and Lodge, 2010). Among countries of the world, Mexico ranks third (behind China and Brazil) in number of known hypogean fish species, with about 12 valid species and several additional taxa of unresolved taxonomic status 
(e.g., infraspecific populations of Astyanax and Rhamdia). This number represents approximately $7 \%$ of stygobitic fishes worldwide (Proudlove, 2010). In Mexico, as is the case globally, most hypogean fishes are ostariophysans. Caecieleotris morrisi is thus a unique taxon in representing the only known obligate cave gobiiform in the Western Hemisphere.

\section{MATERIAL EXAMINED}

Comparative material examined included several eleotrid and gobiid species that occur in the general geographic region of the new taxon, including westcentral Atlantic and eastcentral Pacific drainages.

Awaous banana: LSUMZ 14826, 2, Panama, Darién Province, Puerto La Cantera, 1 April 2011.

Dormitator latifrons: LSUMZ 14555, 1, Honduras, Departamento de Atlántida, E edge of Sambo Creek, 8 January 2011; UF 15255, 1 CS, Mexico, Colima State, mangrove swamp 1.7 mi SW of Tecomán, 1 June 1966.

Dormitator maculatus: LSUMZ 15901, 35, Honduras, Departamento de Colon, Laguna Guaimoreto, 10 September 2011; UF 87885, 1 CS, Florida, Martin County, Danforth Creek on Co Rte 714 about 1 mi E of turnpike, 9 September 1991.

Eleotris amblyopsis: LSUMZ 15635, 2, Honduras, Departamento de Cortés, Barra del Motagua, community of Omoa, 8 September 2011; UF 67681, 28 (1 CS), Costa Rica, Limón Province, Benjamin Creek $1 \mathrm{mi}$ upstream Tortuguero River, 17 August 1969.

Eleotris perniger: LSUMZ 14540, 8, Honduras, Departamento de Atlántida, Cureo River mouth, Refugio de Vida Silvestre, 9 January 2011; UF 27603, 34 (2 CS), Panama, Kuna Yala Province, creek $0.5 \mathrm{mi}$ N of Puerto Obaldia, 4 May 1965.

Erotelis smaragdus civitatum: LSUMZ 4475, 2, Louisiana, Jefferson Parish, Bay Macoin, 9 July 1973.

Gobiomorus dormitor: LSUMZ 15003, 1, Honduras, Departamento de Colon, Barra Sico, Laguna Bacalar, 28 November 2010; UF 27515, 20 (1 CS), Panama, Canal Zone, Gatun Lake, Frijoles Landing, 26 April 1965.

Gobiomorus maculatus: UF 19619, 1 CS, Costa Rica, Puntarenas Province, tidal stream of estuary at Quepos, 2 July 1973.

\section{ACKNOWLEDGMENTS}

We are grateful to D. W. Nelson (UMMZ) for aid with loans and for facilitating collaboration between the authors. C. R. Gilbert (UF) first recognized and brought to the senior author's attention the importance and distinctiveness of this taxon. Curatorial assistance and loans of specimens were arranged by R. R. Robins, L. M. Page, and Z. S. Randall (UF) and C. D. McMahan (LSU). We thank H. Espinosa-Peréz (UNAM) for arranging for permits and depositing the holotype in Mexico, H. L. Jelks (USGS) for assistance with photography, and J. J. Schmitter-Soto (ECOSUR) for providing a Spanish translation of the abstract. Constructive comments on a draft of the manuscript were provided by W. F. Loftus. Partial funding for this work was also supplied by National Science Foundation grant DEB 1354149.

\section{LITERATURE CITED}

Allen, G. R. 1996. Oxyeleotris caeca, a new species of blind cave fish (Eleotridae) from Papua New Guinea. Revue Française d'Aquariologie 23:43-46.

Betancur-R., R., R. E. Broughton, E. O. Wiley, K. Carpenter, J. A. López, C. Li, N. I. Holcroft, D. Arcila, M. Sanciangco, J. C. Cureton, II, F. Zhang, T. Buser, M. A. Campbell, J. A. Ballesteros, A. Roa-Varon, S. Willis, W. C. Borden, T. Rowley, P. C. Reneau, D. J. Hough, G. Lu, T. Grande, G. Arratia, and G. Ortí. 2013. The tree of life and a new classification of bony fishes. PLOS Currents Tree of Life. Edition 1. doi: 10.1371/currents. tol.53ba26640df0ccaee75bb165c8c26288.

Bichuette, M. E., and E. Trajano. 2010. Conservation of subterranean fishes, p. 65-80. In: Biology of Subterranean Fishes. E. Trajano, M. E. Bichuette, and B. G. Kapoor (eds.). Science Publishers, Enfield, New Hampshire.

Castro-Aguirre, J. L., H. S. Espinoza-Pérez, and J. J. Schmitter-Soto. 1999. Ictiofauna estuarino lagunar y vicaria de México. Colección Textos Politécnicos, Serie Biotecnologías, Editorial Limusa, Mexico.

Chakrabarty, P. 2010. Status and phylogeny of Milyeringidae (Teleostei: Gobiiformes), with the description of a new blind cave-fish from Australia, Milyeringa brooksi, n. sp. Zootaxa 2557:19-28.

Chakrabarty, P., M. P. Davis, and J. S. Sparks. 2012. The first record of a trans-oceanic sister-group relationship between obligate vertebrate troglobites. PLOS ONE 7:e44083.

Chakrabarty, P., J. A. Prejean, and M. L. Niemiller. 2014. The Hoosier cavefish, a new and endangered species (Amblyopsidae, Amblyopsis) from the caves of southern Indiana. ZooKeys 412:41-57.

Dzul-Caamal, R., H. F. Olivares-Rubio, C. G. MedinaSegura, and A. Vega-López. 2012. Endangered Mexican fish under special protection: diagnosis of habitat fragmentation, protection, and future-a review, p. 109-130. In: Endangered Species: Habitat, Protection and Ecological Significance. M. E. Lucas-Borja (ed.). Nova Science Publishers, New York.

Eigenmann, C. H. 1909. Cave Vertebrates of America: A Study in Degenerative Evolution. Carnegie Institution of Washington Publication 104, Washington, D.C.

Eschmeyer, W. N., and J. D. Fong. 2016. Species by family/ subfamily. Catalog of Fishes. http://researcharchive. calacademy.org/research/ichthyology/catalog/ SpeciesByFamily.asp. Electronic version accessed 13 May 2016.

Franz, R., J. Bauer, and T. Morris. 1994. Review of biologically significant caves and their faunas in Florida and south Georgia. Brimleyana 20:1-109.

Gill, A. C., and R. D. Mooi. 2012. Thalasseleotrididae, new family of marine gobioid fishes from New Zealand and temperate Australia, with a revised definition of its sister taxon, the Gobiidae (Teleostei: Acanthomorpha). Zootaxa 3266:41-52.

Gómez-Mendoza, L., E. Vega-Peña, M. I. Ramírez, J. L. Palacio-Preto, and L. Galicia. 2006. Projecting land-use change processes in the Sierra Norte of Oaxaca, Mexico. Applied Geography 26:276-290.

Hobbs, H. H., III. 1994. Biogeography of subterranean decapods in North and Central America and the Caribbean region (Caridea, Astacidea, Brachyura). Hydrobiologia 287: 95-104. 
Hobbs, H. H., Jr., H. H. Hobbs, III, and M. A. Daniel. 1977. A review of the troglobitic decapod crustaceans of the Americas. Smithsonian Contributions to Zoology No. 244: 1-183.

Hobbs, H. H., III, and D. M. Lodge. 2010. Decapoda, p. 901967. In: Ecology and Classification of North American Freshwater Invertebrates. Third edition. J. H. Thorp and A. P. Covich (eds.). Academic Press (Elsevier), London.

Hoese, D. F. 1983. Sensory papilla patterns of the cheek lateralis system in the gobiid fishes Acentrogobius and Glossogobius, and their significance for the classification of gobioid fishes. Records of the Australian Museum 35:223230.

Hoese, D. F. 1984. Gobioidei: relationships, p. 588-591. In: Ontogeny and Systematics of Fishes. H. G. Moser, W. J. Richards, D. M. Cohen, M. P. Fahay, A. W. Kendall, Jr., and S. L. Richardson (eds.). American Society of Ichthyologists and Herpetologists Special Publication No. 1. Allen Press, Lawrence, Kansas.

Hoese, D. F., and A. C. Gill. 1993. Phylogenetic relationships of eleotridid fishes (Perciformes; Gobioidei). Bulletin of Marine Science 52:415-440.

Hoese, D., and M. Kottelat. 2005. Bostrychus microphthalmus, a new microphthalmic cavefish from Sulawesi (Teleostei; Gobiidae). Ichthyological Exploration of Freshwaters 16: 183-191.

Hubbs, C. L. 1938. Fishes from the caves of Yucatan. Carnegie Institution of Washington Publication No. 491: 261-295, 4 pl.

Hubbs, C. L., and K. F. Lagler. 2004. Fishes of the Great Lakes Region. Revised edition (by G. R. Smith). University of Michigan Press, Ann Arbor, Michigan.

Huidobro, L., J. J. Morrone, J. L. Villalobos, and F. Álvarez. 2006. Distributional patterns of freshwater taxa (fishes, crustaceans and plants) from the Mexican Transition Zone. Journal of Biogeography 33:731-741.

Jeffery, W. R. 2001. Cavefish as a model system in evolutionary developmental biology. Developmental Biology 231:1-12.

Jeffery, W. R. 2009. Evolution and development in the cavefish Astyanax. Current Topics in Developmental Biology 86:191-221.

Jelks, H. L., S. J. Walsh, N. M. Burkhead, S. ContrerasBalderas, E. Diaz-Pardo, D. A. Hendrickson, J. Lyons, N. E. Mandarak, F. McCormick, J. S. Nelson, S. P. Platania, B. A. Porter, J. J. Schmitter-Soto, E. B. Taylor, and M. L. Warren, Jr. 2008. Conservation status of imperiled North American freshwater and diadromous fishes. Fisheries 33: 372-407.

Johnson, G. D., and E. B. Brothers. 1993. Schindleria: a paedomorphic goby (Teleostei: Gobioidei). Bulletin of Marine Science 52:441-471.

Larson, H. K., R. Foster, W. F. Humphreys, and M. I. Stevens. 2013. A new species of the blind cave gudgeon Milyeringa (Pisces: Gobioidei, Eleotridae) from Barrow Island, Western Australia, with a redescription of M. veritas Whitley. Zootaxa 3616:135-150.

Matamoros, W. A., C. D. McMahan, P. Chakrabarty, J. S. Albert, and J. F. Schaefer. 2015. Derivation of the freshwater fish fauna of Central America revisited: Myer's hypothesis in the twenty-first century. Cladistics 31:177188.

Miller, R. R., W. L. Minckley, and S. R. Norris. 2005. Freshwater Fishes of Mexico. University of Chicago Press, Chicago.
Murdy, E. O., and D. F. Hoese. 2002. Gobiidae, p. 17811796: In: The Living Marine Resources of the Western Central Atlantic. Volume 3: Bony Fishes Part 2 (Opistognathidae to Molidae). FAO Species Identification Guide for Fishery Purposes. K. E. Carpenter (ed.). FAO, Rome.

Niemiller, M. L., T. J. Near, and B. M. Fitzpatrick. 2012. Delimiting species using multilocus data: diagnosing cryptic diversity in the southern cavefish, Typhlichthys subterraneus (Teleostei: Amblyopsidae). Evolution 66:846866.

Niemiller, M. L., and T. L. Poulson. 2010. Subterranean fishes of North America: Amblyopsidae, p. 169-280. In: Biology of Subterranean Fishes. E. Trajano, M. E. Bichuette, and B. G. Kapoor (eds.). CRC Press, Boca Raton, Florida.

Potthoff, T. 1984. Clearing and staining techniques, p. 3537. In: Ontogeny and Systematics of Fishes. H. G. Moser, W. J. Richards, D. M. Cohen, M. P. Fahay, A. W. Kendall, Jr., and S. L. Richardson (eds.). American Society of Ichthyologists and Herpetologists Special Publication 1. Allen Press, Lawrence, Kansas.

Poulson, T. L. 1963. Cave adaptation in amblyopsid fishes. American Midland Naturalist 70:257-290.

Poulson, T. L. 2001. Adaptations of cave fishes with some comparisons to deep-sea fishes. Environmental Biology of Fishes 62:345-364.

Pouyaud, L., Kadarusman, R. K. Hadiaty, J. Slembrouck, N. Lemauk, R. V. Kusumah, and P. Keith. 2012. Oxyeleotris colasi (Teleostei: Eleotridae), a new blind cave fish from Lengguru in West Papua, Indonesia. Cybium 36:521-529.

Protas, M., and W. R. Jeffery. 2012. Evolution and development in cave animals: from fish to crustaceans. WIREs Developmental Biology 1:823-845.

Proudlove, G. S. 2001. The conservation status of hypogean fishes. Environmental Biology of Fishes 62:201-213.

Proudlove, G. S. 2006. Subterranean fishes of the world: an account of the subterranean (hypogean) fishes described up to 2003 with a bibliography 1541-2004. International Society for Subterranean Biology, Moulis, France.

Proudlove, G. S. 2010. Biodiversity and distribution of the subterranean fishes of the world, p. 41-63. In: Biology of Subterranean Fishes. E. Trajano, M. E. Bichuette, and B. G. Kapoor (eds.). Science Publishers, Enfield, New Hampshire. Quiroz-Martínez, B., F. Álvarez, H. Espinosa, and G. Salgado-Maldonado. 2014. Concordant biogeographic patterns among multiple taxonomic groups in the Mexican freshwater biota. PLOS ONE 9(8):e105510.

Romero, A. (Ed.). 2001. The biology of hypogean fishes. Environmental Biology of Fishes 62:1-364.

Romero, A., and K. M. Poulson. 2001. It's a wonderful hypogean life: a guide to the troglomorphic fishes of the world. Environmental Biology of Fishes 62:13-41.

Sabaj Pérez, M. H. (Ed.). 2014. Standard symbolic codes for institutional resource collections in herpetology and ichthyology: an Online Reference. Version 5.0 (22 September 2014). Electronically accessible at http:// www.asih.org/, American Society of Ichthyologists and Herpetologists, Washington, D.C.

SEMARNAT. 2010. Norma Oficial Mexicana NOM-059SEMARNAT-2010, Protección ambiental-Especies nativas de Mexico de flora y fauna silvestres-Categorías de riesgo y especificaciones para su inclusión, exclusión o cambioLista de especies en riesgo. Diario Oficial de la Federación (2a. secc.), 30 December 2010. 
Soares, D., and M. L. Niemiller. 2013. Sensory adaptations of fishes to subterranean environments. BioScience 63: 274-283.

Sparks, J. S., and P. Chakrabarty. 2012. Revision of the endemic Malagasy cavefish genus Typhleotris (Teleostei: Gobiiformes: Milyeringidae), with discussion of its phylogenetic placement and description of a new species. American Museum Novitates 3764:1-28.

Springer, V. G. 1983. Tyson belos: new genus and species of western Pacific fish (Gobiidae, Xenisthminae), with discussions of gobioid osteology and classification. Smithsonian Contributions to Zoology No. 390:1-40.

Thacker, C. E. 2009. Phylogeny of Gobioidei and placement within Acanthomorpha, with a new classification and investigation of diversification and character evolution. Copeia 2009:93-104.

Thacker, C. E. 2011. Systematics of Butidae and Eleotridae, p. 79-85. In: The Biology of Gobies. R. Patzner, J. L. V. Tassell, M. Kovacic, and B. G. Kapoor (eds.). CRC Press, Boca Raton, Florida.

Thacker, C. E., T. P. Satoh, E. Katayama, R. C. Harrington, R. I. Eytan, and T. J. Near. 2015. Molecular phylogeny of Percomorpha resolves Trichonotus as the sister lineage to Gobioidei (Teleostei: Gobiiformes) and confirms the polyphyly of Trachinoidei. Molecular Phylogenetics and Evolution 93:172-179.

Thines, G. 1969. L'Evolution regressive des poissons cavernicoles et abyssaux. Mason et Cie, Paris.

Tornabene, L., Y. Chen, and F. Pezold. 2013. Gobies are deeply divided: phylogenetic evidence from nuclear DNA (Teleostei: Gobioidei: Gobiidae). Systematics and Biodiversity $11: 345-361$.
Trajano, E., M. E. Bichuette, and B. G. Kapoor (Eds.). 2010. Biology of Subterranean Fishes. Science Publishers, Enfield, New Hampshire.

Velázquez, A., E. Durán, I. Ramírez, J.-F. Mas, G. Bocco, G. Ramírez, and J.-L. Palacio. 2003. Land use-cover change processes in highly biodiverse areas: the case of Oaxaca, Mexico. Global Environmental Change 13:175-184.

Weber, A. 2000. Fish and amphibian, p. 109-132. In: Ecosystems of the World: Subterranean Ecosystems. H. Wilkens, D. Culver, and W. F. Humphreys (eds.). Elsevier, Amsterdam.

Weber, A., G. S. Proudlove, and T. T. Nalbant. 1998. Morphology, systematic diversity, distribution, and ecology of stygobitic fishes, p. 1179-1190. In: Encyclopaedia Biospeologica. C. Juberthie and V. Decu (eds.). Société Internationale de Biospéologie, Moulis and Bucarest.

Wiley, E. O., and G. D. Johnson. 2010. A teleost classification based on monophyletic groups, p. 123-182. In: Origin and Phylogenetic Relationships of Teleosts. J. S. Nelson, H.P. Schultze, and M. V. H. Wilson (eds.). Verlag Dr. Friedrich Pfeil, München.

Wilkens, H. 1988. Evolution and genetics of epigean and cave Astyanax fasciatus (Characidae, Pisces), p. 271-367. In: Evolutionary Biology. Vol. 23. M. Hecht and B. Wallace (eds.). Springer, New York.

Wilkens, H. 2005. Fish, p. 241-251. In: Encyclopedia of Caves. D. C. Culver and W. B. White (eds.). Elsevier/ Academic Press, Amsterdam.

Winterbottom, R. 1993. Search for the gobioid sister group (Actinopterygii: Percomorpha). Bulletin of Marine Science 52:395-414. 